УДК $811.111: 81^{\prime} 42(089.3)$

DOI https://doi.org/10.26661/2414-1135-2021-82-2

\title{
КОГНІТИВНИЙ МЕХАНІЗМ КОМПРЕССІЇ АНГЛОМОВНОГО АФОРИЗМУ
}

\author{
Анастасьсва О. A. \\ кандидат філологічних наук, \\ доцент кафедри мовної підготовки \\ Харківський наџіональний технічний університет сільського господарства \\ імені Петра Василенка \\ вул. Алчевских, 44, Харків, Украӥна \\ orcid.org/0000-0003-3856-3741 \\ anastasievaxenia@gmail.com
}

Ключові слова: афоризм, когнітивний механізм компресії, метафоризаиія, імплікація, зіставлення конщептів.
Стаття присвячена дослідженню когнітивного механізму компресії англомовного афоризму. Зроблено обрис підходів до визначення поняття мовної компресії. Інтепретативний та концептуальний аналіз текстів англомовних афоризмів із застосуванням засобів синергетики показав, що компресія в афоризмах призводить до зростання ролі фонових знань, необхідних реципієнту для розуміння імплікації автора. Недомовленість, яка виникає як наслідок компресії, передбачає активну участь реципієнта в декодуванні змісту. Таким чином, механізм компресії працює на формальному рівні як інструмент стиснення тексту, а на змістовному рівні як засіб кодування інформації у вигляді компактних, стислих структур, збільшуючи значимість імплікації. Застосування апарату синергетики дає ключ до розуміння глибинного механізму мовної компресії афоризму. Композиційно структура англомовного афоризму складається з двох елементів: певної думки і авторського міркування з цього приводу. Ці елементи можуть бути не завжди повністю виражені, але вони завжди присутні в афоризмі. Типовою композиційною особливістю афоризму $€$ те, що ці елементи можуть перебувати в конфлікті. Це зумовлює специфічність самоорганізації англомовного афоризму на усіх рівнях. Але двочастинність тексту афоризму $\epsilon$ відбиттям його глибших когнітивних характеристик, які породжують його самоорганізацію. Саме тут проявляється параметр порядку на когнітивному рівні й породжує свій прояв на інших рівнях. 3 когнітивного погляду у двох частинах афоризму відбувається зіставлення двох об'єктів (концептів). У разі імплікації відбувається зіставлення експлікованої та імпліцитної інформації. Дослідження показало, що в англомовних афоризмах компресія відбувається на різних мовних рівнях, зокрема, мовностилістичному (засоби образності, як-от: метафора, метонімія тощо), на рівні синтаксису (еліпсис) та ін. Проте найбільш значущим механізмом компресії в афоризмах є когнітивний, що базується на імплікації, при цьому можлива імплікація культурно значущих передтекстів чи мовних одиниць, лінгвокультурних реалій, а також загальних фонових знань. 


\title{
COGNITIVE MECHANISM OF COMPRESSION IN ENGLISH APHORISM
}

\author{
Anastasieva O. A. \\ Candidate of Philological Sciences, \\ Associate Professor at the Language Training Department \\ Kharkiv Petro Vasylenko National Technical University of Agriculture \\ Alchevskykh str., 44, Kharkiv, Ukraine \\ orcid.org/0000-0003-3856-3741 \\ anastasievaxenia@gmail.com
}

Key words: aphorism, cognitive mechanism of compression, metaphorization, implication, collision of concepts.
The article is devoted to the study of the cognitive mechanism of compression of English aphorisms. The approaches to the definition of the concept of speech compression are outlined. An interpretive and conceptual analysis of the texts of English aphorisms using synergetics has shown that compression in aphorisms causes an increase in the role of background knowledge required by the recipient to understand the author's implication. The innuendo, which arises as a result of compression, involves the active participation of the recipient in decoding the content. Thus, the compression mechanism works at the formal level as a tool for the text compression, and at the content level as a means of encoding information in the form of compact, compressed structures, increasing the importance of implication. The use of the apparatus of synergetics enabled us to understand the deep mechanism of speech compression of an aphorism. Structurally, the English language aphorism consists of two elements: a certain opinion and the author's reasoning on this subject. These elements may not always be fully expressed, but they are always present in the aphorism. A typical compositional feature of the aphorism is that these elements may be in conflict. This determines the specificity of the selforganization of the English aphorism at all levels. But the two-part text of the aphorism is a reflection of its deeper cognitive characteristics, which give rise to its self-organization. It is here that the parameter of order manifests itself at the cognitive level and generates its manifestation at other levels. From a cognitive point of view, there is a comparison of two objects (concepts) in two parts of the aphorism. When implication is used, there is a comparison of explicit and implicit information. The study showed that, in English aphorisms, compression occurs at different language levels, in particular, lingvostylistics (means of imagery, such as metaphor, metonymy, etc.), at the level of syntax (ellipsis), and others. However, the most significant mechanism of cognitive compression in aphorisms is the one based on implications, with the possible implication of culturally significant texts or linguistic units, linguistic and cultural realities, as well as general background knowledge.
Афористичні вислови завжди викликали зацікавленість як вчених, так і широкого загалу. Неординарність цього лінгвістичного та культурного феномена, зокрема, криється в поєднанні краси та глибини думки за умов мінімальної довжини тексту. Механізм когнітивної компресії життєвої мудрості у стислий художній твір потребує детального вивчення.

У лінгвістичній науці $є$ кілька підходів до трактування поняття компресії. У широкому сенсі компресія - «це зумовлене законом мовної економії, вимогами жанру, особливостями інформаційного носія спрощення в процесі обробки або породження тексту його поверхневої структури...» [11, с. 70].
Існує також підхід, в рамках якого тенденція до лінгвістичної компресії трактується в рамках жанрово-стилістичної специфіки [10, с. 260].

До способів інформаційної компресії зараховують семіотичні (лексична, синтаксична компресія та формування мовних стереотипів) і комунікативні (згортання інформації та застосування повторної номінації) [3, с. 242].

Важливо зазначити, що механізм компресії призводить до зростаючої ролі фонових знань, які можуть бути необхідні реципієнту для розуміння імплікації автора [7].

Підставою для компресії когнітивної інформації $€$ контекстуальна верифікованість висловлю- 
вання, що дає змогу реципієнту адекватно сприймати всю семантичну i функціональну повноту навіть скорочених одиниць різного рівня [2].

Дослідники цікавилися когнітивними механізмами компресії змісту в художніх текстах. Зокрема, досліджувався зв'язок з імпліцитністю [4].

Механізм компресії розглядався, насамперед, як інструмент економії простору тексту. Важливою визнано роль компресії в процесі кодування інформації у вигляді компактних та стислих структур [6].

Окрему увагу дослідники приділяли імплікації в афоризмах як базовому чиннику компресіі. При цьому зауважувалося, що «семантична компресія інтертекстуальних включень зумовлює те, що їх актуалізація призводить до асиметрії між синтагматикою і парадигматикою афористичного тексту практично на всіх його мовних рівнях» [5].

Синергетична парадигма надає нові можливості для дослідження властивостей тексту, які залишаються невисвітленими в межах традиційних парадигм. «Синергетичний текст визначається як текст множинного кодування, що містить глибинні смисли, які безпосередньо не спостерігаються, і являє собою сукупність внутрішньотекстових нелінійних відносин і процесів. Маркерами синергетичності, типовими і актуальними для англомовного афоризму, є нестандартні синтагматичні зв'язки лексем, інтертекстуальність, стилістичні фігури, а саме: повтори, порівняння, паралелізм» [8, с. 13-14].

Застосування апарату синергетики дає ключ до розуміння глибинного механізму мовної компресії афоризму. Параметр порядку як найбільш рухливий параметр системи, що діє на всіх рівнях самоорганізації, реалізує цілі дискурсу в тексті, підтексті, контексті [9, с. 15].

Параметр порядку в англомовних афоризмах проявляється у двочастинності тексту. Композиційно структура англомовного афоризму складається 3 двох елементів: певної думки і авторського міркування 3 цього приводу. Ці елементи можуть бути не завжди повністю виражені, але вони завжди присутні в афоризмі. Типовою композиційною особливістю афоризму $\epsilon$ те, що ці елементи можуть перебувати в конфлікті. Це зумовлює специфічність самоорганізації англомовного афоризму на усіх рівнях. Але двочастинність тексту афоризму є відбиттям його глибших когнітивних характеристик, які породжують його самоорганізацію. Саме тут проявляється параметр порядку на когнітивному рівні і породжує свій прояв на інших рівнях [1, с. 13].

На підставі когнітивного аналізу англомовного афоризму можна стверджувати, що найрухомішим параметром у процесі (само)організації афоризму $\epsilon$ його здатність до вільного вибору концепту i його головних атрибутів, які зіставляються із цільовим концептом, його периферійним атрибутом. Прояв цього параметра порядку відбувається матрично: на усіх рівнях композиції афоризму, а також по вертикалі - на когнітивному, прагматичному і мовностилістичному рівні. При цьому той самий параметр порядку на цих рівнях знаходить об'єктивацію по-різному [1, с. 16].

Об'єктом дослідження $є$ англомовний афоризм як тип тексту й дискурсу, предметом - когнітивний механізм компресії смислу та засоби його реалізації в англомовних афоризмах.

Мета статті полягає у встановленні специфіки когнітивного механізму компресії змісту англомовного афоризму. Досягнення поставленої мети передбачає виконання таких завдань: проаналізувати механізми компресії смислу в афористичних висловах; визначити мовностилістичні засоби об' єктивації імпліцитної інформації в англомовних афоризмах.

Виклад основного матеріалу дослідження. Результати дослідження корпусу англомовних афоризмів дають підстави стверджувати, що компресія притаманна англомовним афоризмам, що зумовлено їх жанровою своєрідністю, зокрема лаконічністю та високою інформативною щільністю. При цьому компресія відбувається на усіх рівнях за рахунок різноманітних засобів.

Розглянемо приклад компресії, яка базується на спрощеному синтаксисі, як засобу економії мовленнєвих засобів задля досягнення прагматичного ефекту:

Go to Heaven for the climate, Hell for the company. Mark Twain

Також досить поширеним інструментом компресії в афоризмах є метафоризація: In skating over thin ice, our safety is in our speed. $R$. W. Emerson

$\mathrm{У}$ цьому афоризмі метафора 'skating over thin ice' - ‘nоводження у ризикованій ситуації' викликає весь комплекс асоціацій, який базується на життєвому досвіді. Саме застосування образності дає ефект різниці об'єму того, що було сказано, i того, що малося на увазі, тобто компресії змісту.

Менш поширеним засобом компресії змісту є метонімія, наприклад:

Religion's in the heart, not in the knees. Douglas Jerrod

Тут 'the heart' вживається метонімічно на позначення зовнішнього прояву ритуальності релігії (колінопреклоніння) та протиставляється 'the knees' у значенні щирого вірування.

Проте аналіз корпусу афористичних висловів дає підстави зробити висновок, що найбільш значущим механізмом компресії в афоризмах є когнітивний, що базується на імплікації.

1. Автор може передбачати, що реципієнт ознайомлений із передтекстом, зміст якого зіставляється з експліцитним виразом: 
A sheep in sheep's clothing. Winston Churchill

Цей афоризм передбачає, що реципієнт знайомий, по-перше, з виразом 'a wolf in sheep's clothing' 'вовк в овечій шкурі', який виступає в ролі передтексту, а по-друге, 3 негативним лінгвокультурним наповненням концепту 'вівця'. Саме зіставлення цієї інформації дає змогу декодувати цей стислий вираз як характеристику особи, яка $€$ нерозумною та безхарактерною і саме так і поводиться.

2. But I'm not so think as you drunk I am. J.C. Squire

Каламбур завдяки навмисно зміненому порядку слів імітує незв'язне мовлення нетверезої людини. Для сприйняття вислову реципієнт обов'язково має усвідомлювати цю алюзію. Впізнаваність передтексту викликає емоційну реакцію та зумовлює комунікативний ефект. Базою для застосування механізму компресії $є$ наявність побутового життєвого досвіду в читача (слухача).

3) We have the best government that money can buy. Mark Twain

Цей афоризм апелює до відомого виразу 'the best (something) that money can buy' із значенням 'щось найкращої якості'. Але автор передбачає наявність у реципієнта досвіду та знання про продажність політиків, що зовсім не характеризує їх як найкращих. Саме на цьому зіставленні непоєднуваних концептів будується когнітивний механізм компресії. При цьому компресія базується на знанні фразеологічної одиниці.

4. Розглянемо ще один приклад:

In England, justice is open to all - like the Ritz Hotel. Sir James Mathew Douglas Jerrod

Готель Ritz - це фешенебельний готель, який уособлює розкіш та багатство та пишається своїми видатними гостями; перебування в ньому доступне лише еліті суспільства. У цьому афоризмі генералізуючий маркер 'all' протиставляється тому обмеженому колу осіб, які насправді наділені ексклюзивним правом доступу. Обізнаність реципієнта щодо цього факту є кодовим ключем до розуміння вислову про ступінь відкритості правосуддя.

Висновки. Механізм компресії відіграє важливу роль не тільки у процесі скорочення об'єму тексту афоризму, але й у процесі кодування інформації у вигляді компактних, стислих вербальних і невербальних структур. 3 одного боку, імплікації збільшують смислове навантаження, а $з$ іншого вони служать ключами до розуміння смислу афоризму. В англомовних афоризмах компресія відбувається на різних мовних рівнях, зокрема, мовностилістичному (засоби образності, як-от: метафора, метонімія тощо), на рівні синтаксису (еліпсис) та ін. Проте найбільш значущим механізмом компресії в афоризмах є когнітивний, що базується на імплікації, при цьому можлива імплі- кація культурно значущих передтекстів чи мовних одиниць, лінгвокультурних реалій, а також загальних фонових знань.

Перспективу подальших розробок вбачаємо в проведенні системного, матричного аналізу прояву параметра порядку на усіх рівнях афоризму.

\section{ЛITЕРАТУРА}

1. Анастасьєва О.А. Англомовний афоризм: прагмастилістичний та когнітивний аспекти : автореф. дис. ... канд. філол. наук : 10.02.04. Запоріжжя, 2017. 20 с.

2. Бредихин С.Н., Серебрякова С.В., Лиховид А.А. Способы компрессии когнитивной информации в научно-популярном тексте. Актуальные проблемы филологии и педагогической лингвистики. 2019. Вып. 3. С. 139-145.

3. Валгина Н.С. Теория текста. Москва : Логос, 2003. $280 \mathrm{c}$.

4. Голованова Е.И., Канашина С.В. Когнитивные механизмы компрессии оценочного смысла в художественном тексте. Общероссийский академический научный журнал "Вопросы когнитивной лингвистики». 2017. No 3 (52). C. 31-36.

5. Землянская Е.В. Структурно-семантические и функциональные особенности стилевой интертекстуальности в англоязычном афоризме : дис. ...канд. филол. наук : 10.02.04. Санкт-Петербург, 2004. 209 с.

6. Канашина С.В. Когнитивный механизм компрессии в интернет-мемах. Филологические науки в МГИМО. 2015. № 1. С. 30-39.

7. Лухьенбрурс Д. Дискурсивный анализ и схематическая структура. Bопросы языкознания. 1996. № 2. C. 141-155.

8. Муратова Е.Ю. Лингвосинергетика поэтического текста. Минск : Изд-во «Простобук». 2011. $219 \mathrm{c}$.

9. Пихтовникова Л.С. Самоорганизация речевых произвдений: информационно-когнитивный аспект. Синергетика в филологических исследованиях : коллективная монография / под общ. ред. проф. Л.С. Пихтовниковой. Харьков : ХНУ им. В. Н. Каразина, 2015. С. 102-135.

10. Умерова М.В. Языковая компрессия: виды и уровни реализации. Актуальные вопросы современной науки. 2011. Вып. 17. Ч. 1. C. 260-269.

11. Шагланова Е.А. Использование иноязычных слов в компрессии текста. Вестник БГУ. 2013. № 11. С. 70-75.

\section{REFERENCES}

1. Anastasieva, O.A. (2017). Anglomovniy aforizm: pragmastilIstichniy ta kognItivniy aspekti. [English aphorism: pragmastylistic and cognitive 
aspects] :dis. ...kand. filol. nauk : 10.02.04. Zaporizhzhya, $20 \mathrm{p}$.

2. Bredihin, S.N., et al. (2019). Methods of compression of cognitive information in popular science text. [Sposoby kompressii kognitivnoy informatsii $\mathrm{v}$ nauchno-populyarnom tekste]. Aktualnyie problemyi filologii i pedagogicheskoy lingvistiki, 2019, issue 3, pp. 139-145.

3. Valgina, N.S. (2003). Theory of text. [Teoria teksta]. Moscow, Logos, 280 p.

4. Golovanova, Ye.I., Kanashina S.V. (2017) Cognitive mechanisms of compression of axiological meaning in a literary text. [Kognitivnyie mehanizmyi kompressii otsenochnogo smyisla $\mathrm{v}$ hudozhestvennom tekste]. Voprosy kognitivnoi lingvistiki, no 3 (52), pp. 31-36.

5. Zemlyanskaya Ye.V. (2004). Structural-semantic and functional features of stylistic intertextuality in an English. [Strukturno-semanticheskie i funktsionalnyie osobennosti stilevoy intertekstualnosti $\mathrm{v}$ angloyazyichnom aforizme] : dis. ...kand. filol. nauk : 10.02.04. Sankt-Peterburg, 209 p.

6. Kanashina S.V. (2015) Cognitive mechanism of compression in Internet memes. [Kognitivnyiy mehanizm kompressii $\mathrm{v}$ internet-memah]. Filologicheskie nauki v MGIMO, no 1, pp. 30-39.

7. Luhenbrurs, D. (1996). Discursive analysis and schematic structure. [Diskursivnyiy analiz i shematicheskaya struktura]. Voprosy yazyikoznaniya, no 2, pp. 141-155.

8. Muratova, Ye.Yu. (2011). Linguosynergetics of a poetic text [Lingvosinergetika poeticheskogo teksta]. Minsk, «Prostobuk», 219 p.

9. Pihtovnikova, L.S. (2015). Self-organization of speech work: information-cognitive aspect. [Samoorganizatsiya rechevyih proizvdeniy: informatsionno-kognitivnyiy aspekt]. Sinergetika v filologicheskih issledovaniyah. V.N. Karazin KhNU, pp. 102-135.

10. Umerova, M.V. (2011). Language Compression: Types and Levels of Realization. [Yazyikovaya kompressiya: vidyi i urovni realizatsii]. Actual Problems of Modern Science, no 17 (1), pp. 260-269.

11. Shaglanova, Ye.A. (2013). Use of foreign words in text compression. [Ispolzovanie inoyazyichnyih slov v kompressii teksta]. Vestnik BSU, no 11, pp. $70-75$. 